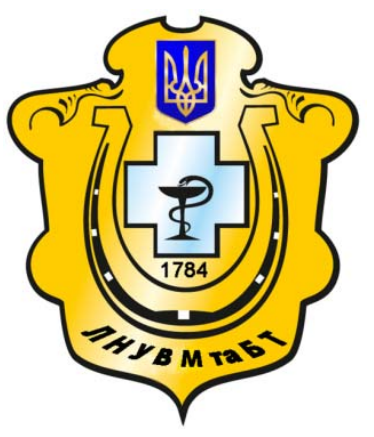

Науковий вісник Львівського національного університету ветеринарної медицини та біотехнологій імені С.3. Гжицького

Scientific Messenger of Lviv National University of Veterinary Medicine and Biotechnologies named after S.Z. Gzhytskyj

doi:10.15421/nvlvet6634

ISSN 2413-5550 print

ISSN 2518-1327 online

$\underline{\text { http://nvlvet.com.ua/ }}$

УДК 619:612.017:619:615.37:636.92

\title{
Вплив профілактичного протипневмококового засобу «Пневмо-Про» на морфологічні зміни органів імунної системи кролів
}

\author{
Ю.Г. Сторчак, Я.В. Кісера \\ juliettus1@gmail.com
}

\begin{abstract}
Львівський національний університет ветеринарної медицини та біотехнологій імені С.3. Гжицького, вул. Пекарська, 50, м. Львів, 79010, Украӥна
\end{abstract}

\begin{abstract}
Представлені результати гістологічних досліджень органів імунної системи кролів після введення їм профілактичного препарату «Пневмо-Про», до складу якого входить два компоненти: Streptococcus pпеитопіае $i$ 4\%-ий спиртововодний екстракт прополісу. Встановлено вплив розробленого профілактичного протипневмококового препарату «Пневмо-Про» на структурно-функціональні особливості органів імунної системи кролів. Попередні дослідження з розробки профілактичного препарату «Пневмо-Про» показали посилення поствакиинального імунітету при застосуванні препаратів на основі прополісу. Гістологічними дослідженнями дивертикулу клубової кишки і червоподібного відростка встановлено, щчо в иентрі підслизових лімфоїдних вузликів знаходиться значна кількість лімфобластів, досить часто візуалізуються мітози лімфоцитів. У куполі підслизових лімфоїдних вузликів розташовуються великі, середні та малі лімфоцити, макрофаги. Корона лімфоїдних вузликів містить переважно лімфоцити різного ступеня зрілості. Некротизовані лімфоцити зустрічаються рідко. У власній пластиниі слизової оболонки і в підслизовій основі у порівнянні з контрольною групою збільшується кількість об'ємних підслизових скупчених лімфоїдних вузликів. Більшість скупчених лімфоїних вузликів розташовуються під криптами, лише поодинокі з них контактують із просвітом кишечника. За гістологічного дослідження червоподібного відростка тварин дослідної групи, яким вводили «Пневмо-Про», встановлено, щзо по периферії від лімфобластів розташовуються В-лімфоцити, макрофаги і інтердигітуючі клітини. Досить часто візуалізуються мітози лімфоїдних елементів. Деякі лімфоцити піддаються некротичним змінам, внаслідок чого між лімфоїдними елементами присутні невеликі проміжки. Периферична частина лімфоїдних вузликів $і$ міжфолікулярна зона містять значну кількість $T$ лімфочитів. Над верхньою частиною багатьох фолікулів розташовуються крипти. У власній пластинці $і$ в підслизовій основі червоподібного відростка розташовуються численні, об'ємні скупчення лімфоїдної тканини, які формують підслизові скупчення лімфоїдних вузликів. Проведені дослідження вказують на підвищення функиіональної активності неспецифічних факторів резистентності та імунобіологічної реактивності організму тварин після введення їм профілактичного протипневмококового препарату «Пневмо-Про».
\end{abstract}

Ключові слова: імунізація, пневмококова інфекиія, специфічна профілактика, імунітет, дивертикул клубової кишки, червоподібний відросток, кролі, лімфоїдні вузлики, реактивний центр, лімфочити.

\section{Влияние профилактического противопневмококкового средства «Пневмо-Про» на морфологические изменения в органах иммунной системы кроликов}

\author{
Ю.Г. Сторчак, Я.В. Кисера \\ juliettus1@gmail.com
}

Львовский национальныцй университет ветеринарной медицины и биотехнологий имени С.3. Гжицкого, ул. Пекарская, 50, г. Львов, 79010, Украина

Citation:

Storchak, Y.G., Kisera, Y.V. (2016). The effect of the preventive antipneumococcal drug «Pneumo-Pro» for the morphological changes in the rabbit’s immune system organs. Scientific Messenger LNUVMBT named after S.Z. Gzhytskyj, 18, 2(66), 166-175. 
Представлены результаты гистологических исследований органов иммунной системы кроликов после введения им профилактического препарата «Пневмо-Про», в состав которого входит два компонента: Streptococсиs pпеитопіае и 4\% ный спиртово-водный экстракт прополиса. Установлено влияние разработанного профилактического протипневмококового препарата «Пневмо-Про» на структурно-функичональные особенности органов иммунной системы кроликов. Предыдущие исследования по разработке профилактического препарата «Пневмо-Про» показали усиление поствакиинального иммунитета при применении препаратов на основе прополиса. Гистологическими исследованиями дивертикула подвздошной кишки и червеобразного отростка установлено, что в центре подслизистых лимфоидньх узелков находится значительное количество лимфобластов, достаточно часто визуализируются митозы лимфоцитов. В куполе подслизистых лимфоидных узелков располагаются крупные, средние и малье лимфоцить, макрофаги. Корона лимфоидньх узелков содержит преимущественно лимфоциты различной степени зрелости. Некротизированные лимфоцитьл встречаются редко. В собственной пластинке слизистой оболочки и в подслизистой основе по сравнению с контрольной группой увеличивается количество объемных скученных лимфоидных узелков. Большинство лимфоидных узелков располагается под криптами, лишь единичные из них контактируют с просветом кишечника. Гистологическими исследованиями червеобразного отростка животных опытной группьл, которым вводили «Пневмо-Про», установлено, что по периферии от лимфобластов располагаются В-лимфоциты, макрофаги и интердигитируюшие клетки. Достаточно часто визуализируются митозы лимфоидных элементов. Некоторые лимфоциты подвергаются некротическим изменениям, в результате чего между лимфоидными элементами присутствуют небольиие промежутки. Периферическая часть лимфоидных узелков и межфолликулярная зона содержат значительное количество Т-лимфочитов. Над верхней частью многих фолликулов располагаются криптьл. В собственной пластинке и в подслизистой основе червеобразного отростка располагаются многочисленные, объемные скопления лимфоидной ткани, которые формируют подслизистые скопления лимфоидных узелков. Проведенные исследования указывают на повышение функциональной активности неспецифических факторов резистентности и иммунобиологической реактивности организма животных после введения им профилактического протипневмококового препарата «Пневмо-Про».

Ключевые слова: иммунизация, пневмококковая инфекция, специцфическая профилактика, иммунитет, дивертикул подвздошной кишки, червеобразный отросток, кролики, лимфоидные узелки, реактивный центр, лимфоцитьл.

\title{
The effect of the preventive antipneumococcal drug «Pneumo-Pro» for the morphological changes in the rabbit's immune system organs
}

\author{
Y.G. Storchak, Y.V. Kisera \\ juliettus1@gmail.com \\ Lviv National University of Veterinary Medicine and Biotechnologies named after S.Z. Gzhytskyi, \\ Pekarska Str., 50, Lviv, 79010, Ukraine
}

There are results of the histological research of the immune system organs of rabbits after injection with a prophylactic drug "Pneumo-Pro», which includes two components: Streptococcus pneumoniae and 4\% ethanol-water extract of propolis. Tentative reseaches on the development of preventive drug "Pneumo-Pro» showed enhancement of post-vaccination immunity in the application on the basis of propolis preparations. Histological reseaches of the diverticulum of the ileum and appendix found a significant amount of lymphoblasts, frequently visualized mitosis of lymphocytes in the center of submucosal lymphoid nodules is. Large, medium and small lymphocytes, macrophages are located in the dome of submucosal lymphoid nodules. The crown of the lymphoid nodules contains mainly lymphocytes of different maturity. Necrotic cells are rare. There is increase the amount of volume crowded lymphoid nodules in the lamina propria and submucosa in compare with the control group. Most of lymphoid nodules are located under the crypts, only a few of them are in contact with the intestinal lumen. Histological reseaches of the appendix of the experimental group of animals injected with «Pneumo-Pro» found B-lymphocytes, macrophages and interdigitive cells are located in the periphery of the lymphoblasts. Quite often mitosis of lymphoid cells are visualized. Some lymphocytes are exposed with necrotic changes, resulting in small intervals are present between lymphoid elements. The peripheral part of the lymphoid nodules and interfollicular zone contain a significant number of T-lymphocytes. Crypts are placed above the top of many follicles. In the lamina propria and submucosa of the appendix there are numerous, voluminous accumulations of lymphoid tissue, which form the clusters of submucosal lymphoid nodules. The reseaches indicate an increase in the functional activity of nonspecific factors of resistance and immunobiological reactivity of organism of animals after injection with a prophylactic drug «Pneumo-Pro».

Key words: immunization, pneumococcal infection, specific prevention, immunity, diverticulum of the ileum, appendix, rabbits, lymphoid nodules, reactive center lymphocytes.

\section{Вступ}

3 моменту першого опису пневмококів у плевральній рідині хворих на пневмонію тварин інтерес до вивчення цих мікроорганізмів постійно зростає. Поширеність і різноманітність захворювань, що викликаються пневмококами, їх унікальна здатність розвитку резистентності до антимікробних препаратів, що істотно знижує ефективність терапії, викликає необхідність комплексного підходу до їх дослідження 3 подальшою потенційною розробкою нових профілактичних та лікувальних засобів.

Проблема підвищення збереження молодняку худоби, підтримки імунного статусу і загальної неспецифічної резистентності дорослого поголів'я розглядається в даний час, як актуальна і комплексна, в якій поряд 3 такими чинниками, як навколишнє середовище і збудник, важлива роль відводиться імунологічній реакції організму (Storchak, 2014; Kisera and Storchak, 2014). 
Специфічна профілактика при пневмококовій септицемії недостатня, так як самі вакцини у відповідній фазі імунізації здатні пригнічувати опірність організму до збудників інфекції. Застосування тільки вакцинації при зниженій функціональній активності неспецифічних факторів резистентності та імунобіологічної реактивності організму телят малоефективне (Shevchenko, 2009). Тому необхідні пошуки засобів і розробка схем застосування стимуляторів імунної відповіді на антиген, використання яких спрямоване на посилення фізіологічних можливостей організму.

У науковій літературі рідко трапляються дані, що містять детальний опис морфологічного стану центральних і периферичних органів імунної системи i їх імуноморфологічні перебудови після застосування вакцин, а також за дії імуностимуляторів. Такі важливі органи периферичної імунної системи, як лімфоїдний дивертикул клубової кишки і червоподібний відросток, в основному є поза увагою вітчизняних вчених. Червоподібний відросток в зв'язку з насиченістю лімфоїдними елементами ще називають мигдалинами черевної порожнини, а спеціалізований епітелій лімфоїдних вузликів здатний захоплювати антигенний матеріал (Datchenko and Vorob'ev, 2009).

Проведені попередні дослідження з розробки профілактичного препарату «Пневмо-Про» показали посилення поствакцинального імунітету при застосуванні препаратів на основі прополісу (Storchak, 2014; Storchak and Kisera, 2014; Storchak, 2015; Kisera and Storchak, 2015).

Мета $i$ завдання досліджень: Встановити вплив розробленого профілактичного протипневмококового препарату «Пневмо-Про» на структурнофункціональні особливості органів імунної системи кролів.

\section{Матеріал і методи досліджень}

Дослідження проводилися на кафедрі нормальної та патологічної морфології і судової ветеринарії Львівського національного університету ветеринарної медицини та біотехнологій імені С.З. Гжицького. Для досліду за принципом аналогів було підібрано 8 кролів двомісячного віку, з яких було сформовано одну контрольну і одну дослідну групи. Тваринам дослідної групи вводили профілактичний препарат «Пневмо-Про», до складу якого входить два компоненти: Streptococcus pneumoniae i 4\%-ий спиртово-водний екстракт прополісу. Препарат вводили внутрішньом'язово двічі 3 інтервалом 14 днів в дозі 0,5 мл при першому введенні і 1 мл при другому введенні. Тваринам контрольної групи вводили фізіологічний розчин натрію хлориду. Забій тварин проводили на 45-й день після введення препарату.

Розтин тварин проводили за методом Шора (Goral's'kyj, 2005). Для гістологічних досліджень відбирали шматочки дивертикулу клубової кишки і чер- воподібного відростка відразу після забою тварин і фіксували в 10-12\% охолодженому розчині нейтрального формаліну з подальшим заливанням в парафін за схемою, запропонованою І. Роксиним і Л.Б. Левінсоном (Roksin and Levinson, 1957). Зафіксовані шматочки товщиною 2 мм промивали у воді 30 хв, після чого підсушували на фільтрувальному папері і проводили через спирти $\left(75,96\right.$ і $100^{\circ}$ для зневоднення і знежирення протягом доби в кожному 3 спиртів). Потім просочували розчинником парафіну ксилолом 1,5 год.

3 ксилолу шматочки переносили в насичений розчин парафіну у ксилолі на 1,5 години при температурі $37^{\circ} \mathrm{C}$. Після чого їх переносили в порцелянові чашки i заливали розплавленим парафіном з наступним швидким охолодженням у холодильній камері. Після затвердіння парафіну шматочки нарізали з парафіном і наклеювали на дерев'яні кубики. Парафінові зрізи виготовляли на санному мікротомі МC-2. Товщина зрізів не перевищувала 10 мкм. 3 метою виявлення морфології клітин і тканин застосовували фарбування гематоксиліном Караці і еозином, а також метиленовим-зеленим і піроніном G за Браше (Shishkov and Naletov, 1980; Merkulov, 1996; Vol'fgans, 2007).

\section{Результати та їх обговорення}

За гістологічного дослідження органів імунної системи тварин контрольної групи виявлено, що слизова оболонка дивертикула клубової кишки містить поодинокі невисокі ворсинки неправильної форми, а також неглибокі крипти з досить широким просвітом. У криптах проглядається значна кількість келихоподібних клітин. У епітеліальному пласті поміж епітеліоцитами візуалізуються лімфоцити та поодинокі нейтрофільні гранулоцити.

Судини слизової оболонки та підслизової основи помірно наповнені кров'ю. Строма слизової оболонки та підслизової основи утворена пухкою сполучною тканиною, містить поодинокі лімфоцити, плазматичні клітини та незначну кількість нейтрофільних гранулоцитів. У власній пластинці слизової оболонки і в підслизовій основі розташовуються чисельні, об'ємні підслизові скупчені лімфоїдні вузлики, неправильної округлої або видовженої форми, з овальним куполом, що прилягає до слизової оболонки, які майже повністю заповнюють проміжки між криптами та займають значний об'єм підслизової основи (рис. 1).

Клітинний склад підслизових скупчених лімфоїдних вузликів представлений клітинами лімфоїдного ряду різного ступеня зрілості. У куполі підслизових скупчених лімфоїдних вузликів розташовуються великі, середні та малі лімфоцити, макрофаги, плазматичні клітини (рис. 2).

Слизова оболонка червоподібного відростка контрольної групи тварин вкрита добре помітними неглибокими криптами, які розташовані в напрямку підслизової основи. 


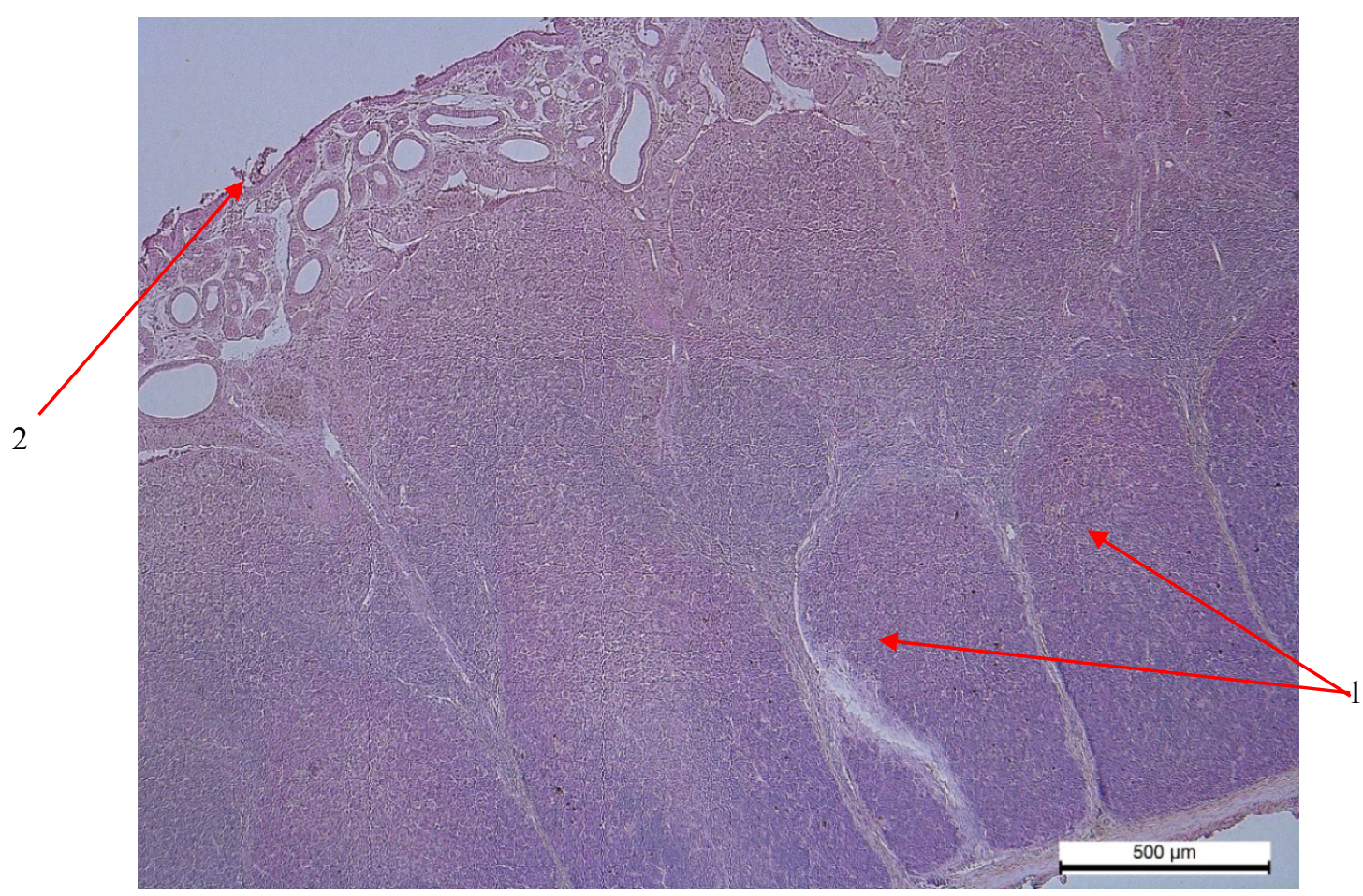

Рис. 1. Дивертикул клубової кишки кролів контрольної групи 1 - лімфоїдні вузлики; 2 - слизова оболонка Гематоксилін-еозин $\times 50$

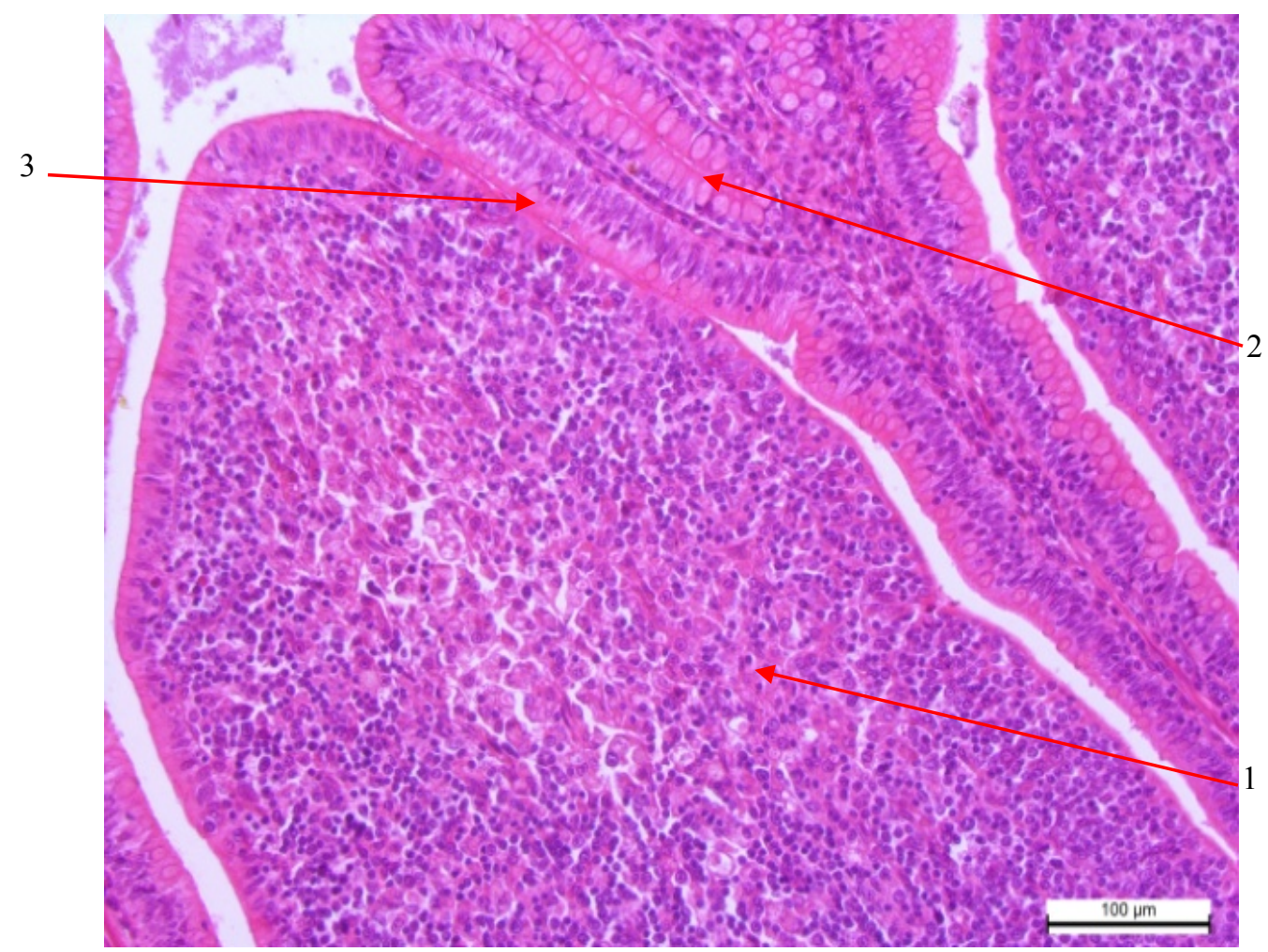

Рис. 2. Дивертикул клубової кишки кролів контрольної групи 1 - лімфоїдний вузлик; 2 - крипти; 3 - келихоподібні клітини Гематоксилін-еозин 200 
Крипти вистелені одношаровим призматичним епітелієм, у складі якого переважають стовпчасті епітеліоцити. На дні кишкових крипт досить часто зустрічаються клітини Панета, що містять у своїй цитоплазмі ацидофільні гранули. Також тут розташовані недиференційовані (камбіальні) епітеліоцити і ендокринні клітини (рис. 3).
Власна пластинка слизової оболонки без різкої межі переходить у підслизову основу. У власній пластинці і в підслизовій основі помітні скупчення лімфоїдної тканини у вигляді вторинних лімфоїдних вузликів. Лімфоїдні фолікули майже повністю заповнюють проміжки між криптами і займають значний обсяг підслизової основи.

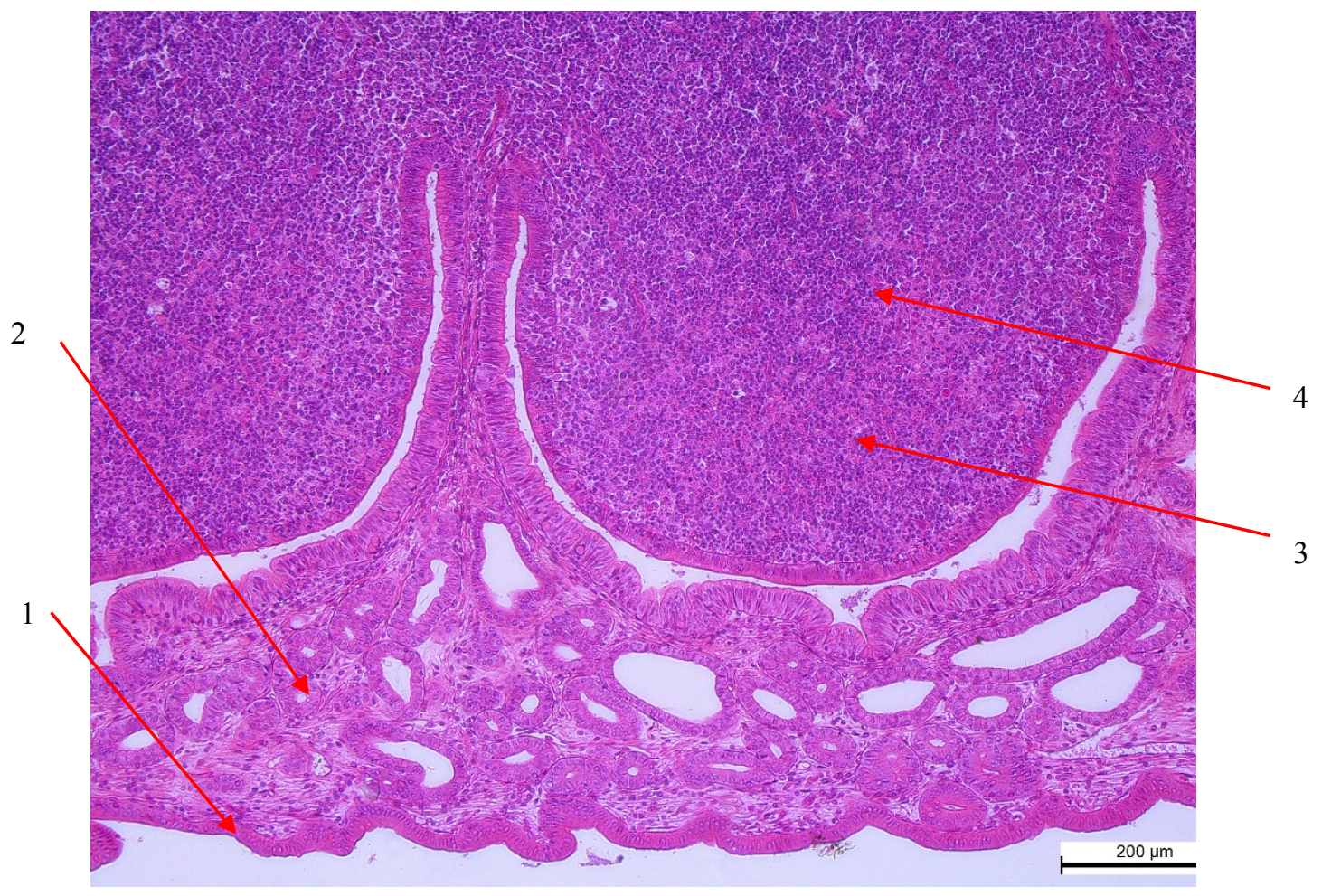

Рис. 3. Червоподібний відросток кролів контрольної групи

1 - слизова основа; 2 - підслизова основа;

3 реактивний центр лімфоїдного вузлика; 4 - клітинні елементи

Гематоксилін-еозин х 100

Переважна більшість вторинних лімфоїдних фолікулів конусоподібної форми. Над верхньою частиною фолікулів розташовуються крипти. Деякі вторинні лімфоїдні вузлики з куполоподібною верхівкою контактують 3 просвітом червоподібного відростка. У вказаній ділянці лімфоїдні фолікули вкриті переважно М-клітинами.

Клітинний склад підслизових скупчених лімфоїдних вузликів гетерогенний. У центрі розташовуються проліферуючі В-лімфобласти, які формують реактивний центр. Дещо по периферії є помірна кількість Влімфоцитів. Міжфолікулярні зони переважно заповнені Т-лімфоцитами. Також в складі паренхіми підслизових лімфоїдних вузликів є макрофаги. Подекуди візуалізуються інтердигітуючі клітини.
Судини слизової оболонки і підслизової основи помірно розширені. Пухка сполучна тканина містить фібробласти, колагенові, еластичні і ретикулярні волокна, поодинокі лімфоцити і плазматичні клітини. У стромі, особливо поблизу лімфатичних фолікулів, кількість лімфоїдних елементів дещо більше.

Гістологічними дослідженнями дивертикулу клубової кишки кролів дослідної групи після введення їм препарату «Пневмо-Про» встановлено, що у складі крипт розташовується значна кількість келихоподібних клітин. В окремих ділянках слизової оболонки, особливо в криптах, рідше на поверхні ворсинок, зростає кількість келихоподібних клітин. На поверхні слизової оболонки наявна помірна кількість слизу (рис. 4, 5). 


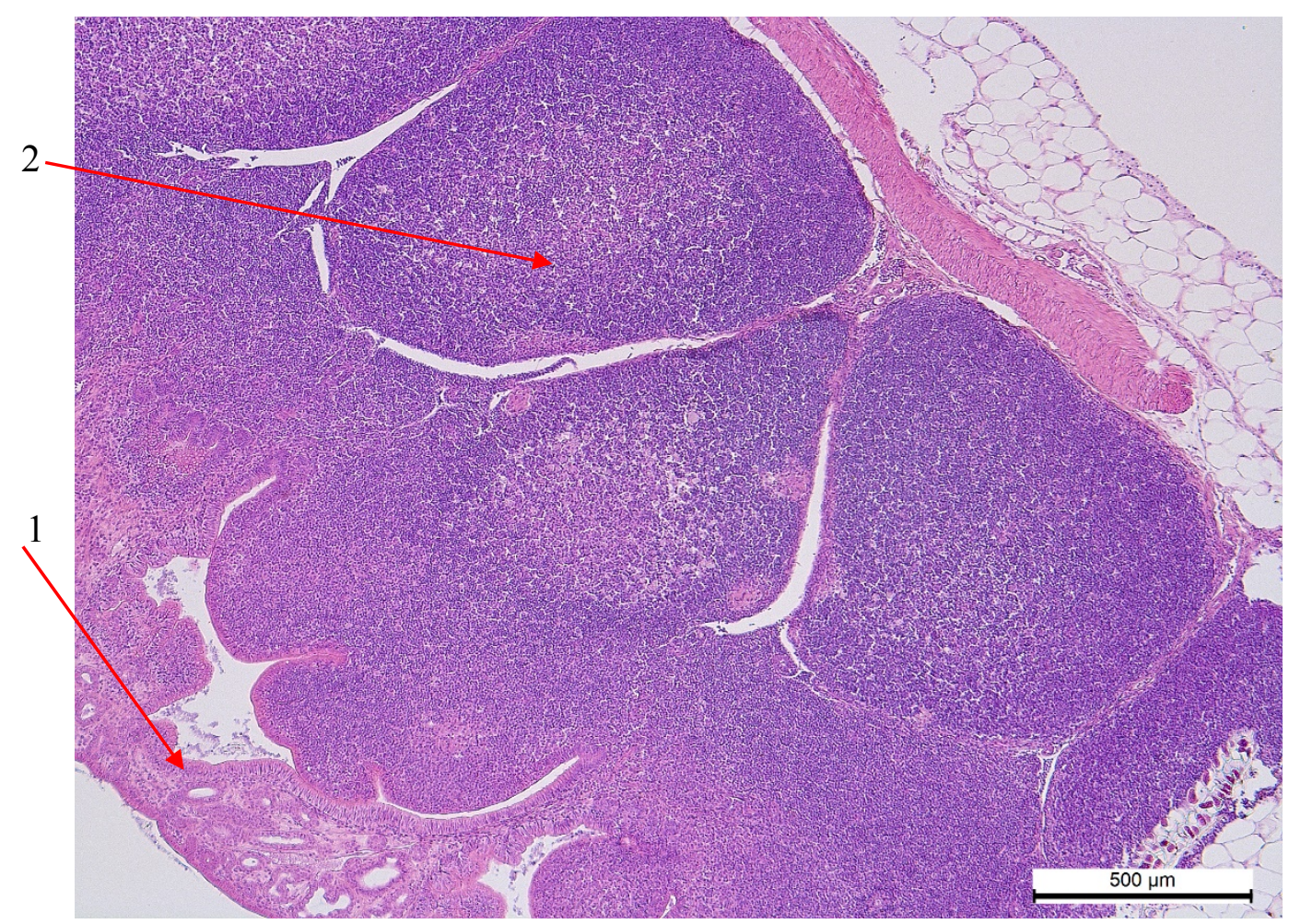

Рис. 4. Дивертикул клубової кишки кролів дослідної групи 1 - келихоподібні клітини; 2 - лімфоїдний вузлик Гематоксилін-еозин $\times 400$

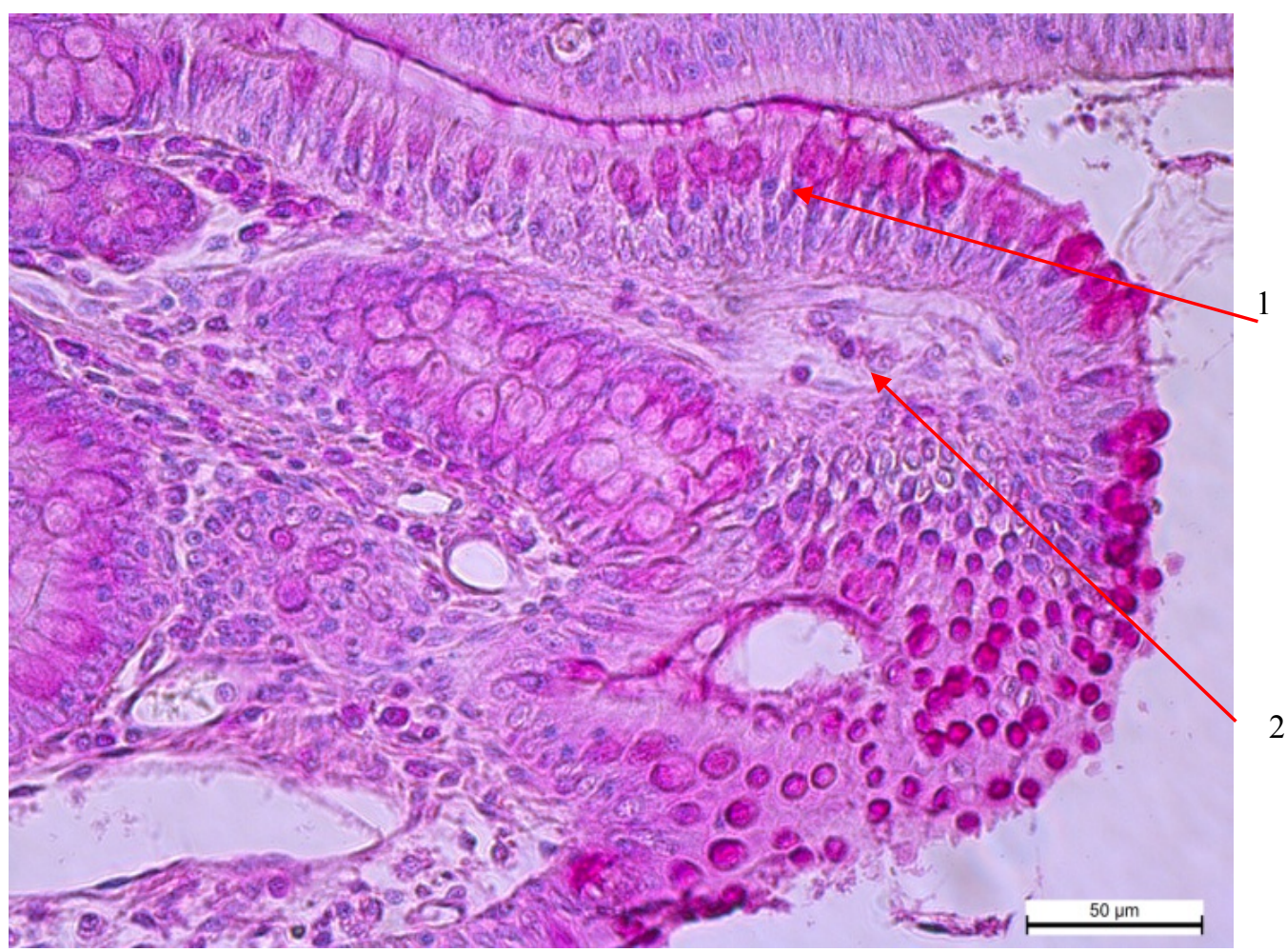

Рис. 5. Дивертикул клубової кишки кролів дослідної групи

1 - келихоподібні клітини; 3 - плазматичні клітини Метиленовий-зелений та піронін $G$ за Браме $x 400$ 
У власній пластинці слизової оболонки і в підслизовій основі у порівнянні з контрольною групою збільшується кількість об'ємних підслизових скупчених лімфоїдних вузликів, неправильної округлої або видовженої форми, з овальним куполом, що прилягає до слизової оболонки. Більшість скупчених лімфоїдних вузликів розташовуються під криптами, лише поодинокі 3 них контактують із просвітом кишечника (рис. 6).

У центрі підслизових скупчених лімфоїдних вузликів порівняно 3 контрольною групою збільшується кількість лімфобластів, які формують світлий (реактивний) центр. Досить часто візуалізуються мітози лімфоцитів. У куполі підслизових скупчених лімфоїдних вузликів розташовуються великі, середні та малі лімфоцити, макрофаги. Корона лімфоїдних вузликів містить переважно лімфоцити різного ступеня зрілості. Некротизовані лімфоцити зустрічаються рідко.
За гістологічного дослідження червоподібного відростка кролів після введення їм «Пневмо-Про» виявлено, що слизова оболонка вкрита добре помітними неглибокими криптами, які простягаються в напрямку підслизової основи. Утворення одних крипт помірно широке, інші - звужені. Поодинокі крипти заповнені надмірною кількістю слизу і десквамованого клітинами (переважно ентероцити і келихоподібні клітини).

У складі епітеліального пласта, крім одношарового стовпчастого епітелію, також є келихоподібні клітини, М-клітини і ентероендокриноцити. На дні кишкових крипт візуалізуються клітини Панета, які у своїй цитоплазмі містять ацидофільні гранули. У зазначеній зоні також розташовуються недиференційовані (камбіальні) епітеліоцити і ендокринні клітини. В окремих криптах досить різко зростає кількість келихоподібних клітин.

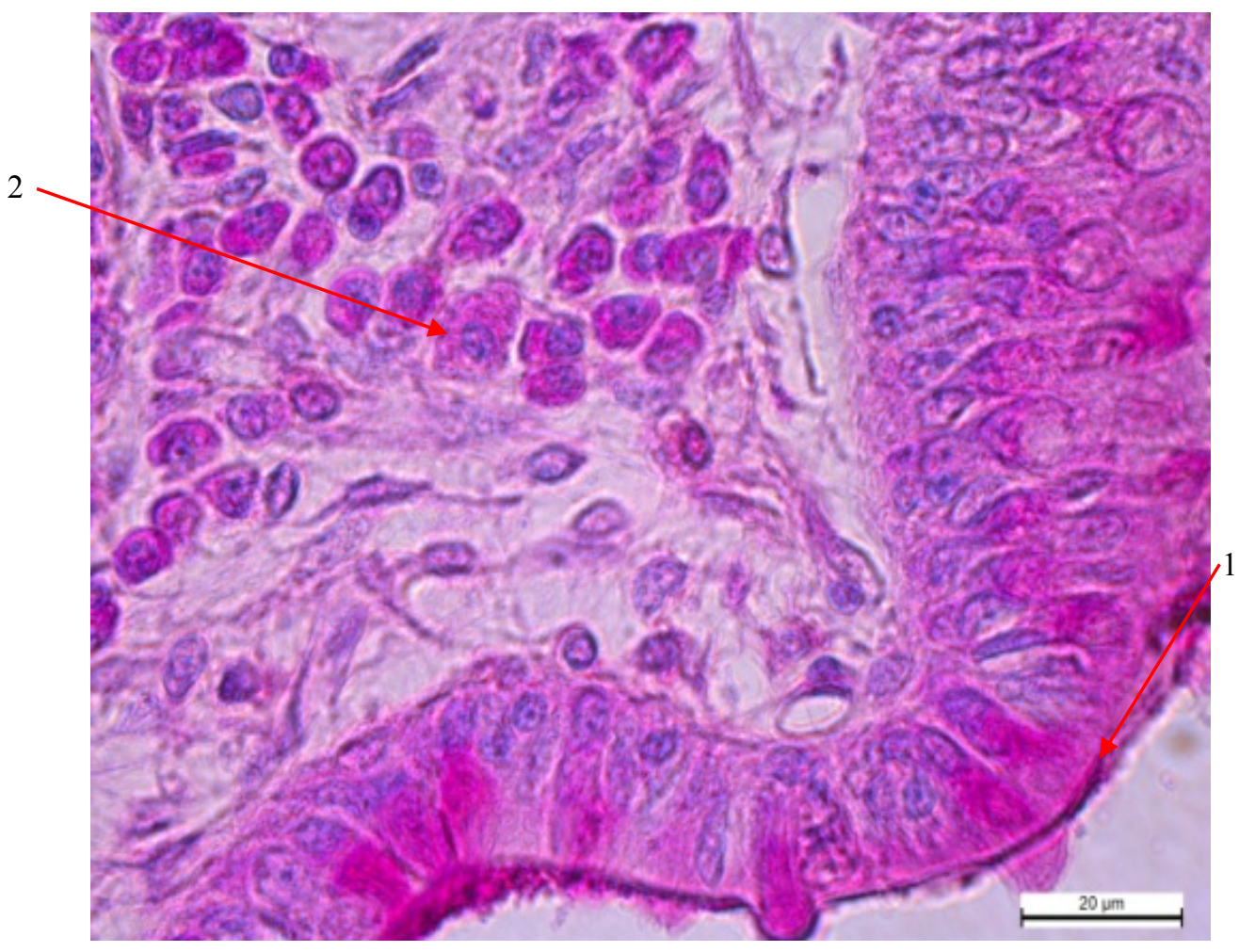

Рис. 6. Дивертикул клубової кишки кролів дослідної групи

1 - слизова оболонка; 2 - плазматичні клітини

Метиленовий-зелений та піронін $G$ за Браше 1000

У власній пластинці і в підслизовій основі розташовуються численні, об'ємні скупчення лімфоїдної тканини, які формують підслизові скупчення лімфоїдних вузликів, центр яких утворений проліферуючими лімфобластами (рис. 7).

По периферії від лімфобластів розташовуються Влімфоцити, макрофаги і інтердигітуючі клітини. Досить часто візуалізуються мітози лімфоїдних елемен- тів. Деякі лімфоцити піддаються некротичним змінам, внаслідок чого між лімфоїдними елементами присутні невеликі проміжки (рис. 8).

Периферична частина лімфоїдних вузликів і міжфолікулярна зона містять значну кількість Тлімфоцитів. Над верхньою частиною багатьох фолікулів розташовуються крипти. 


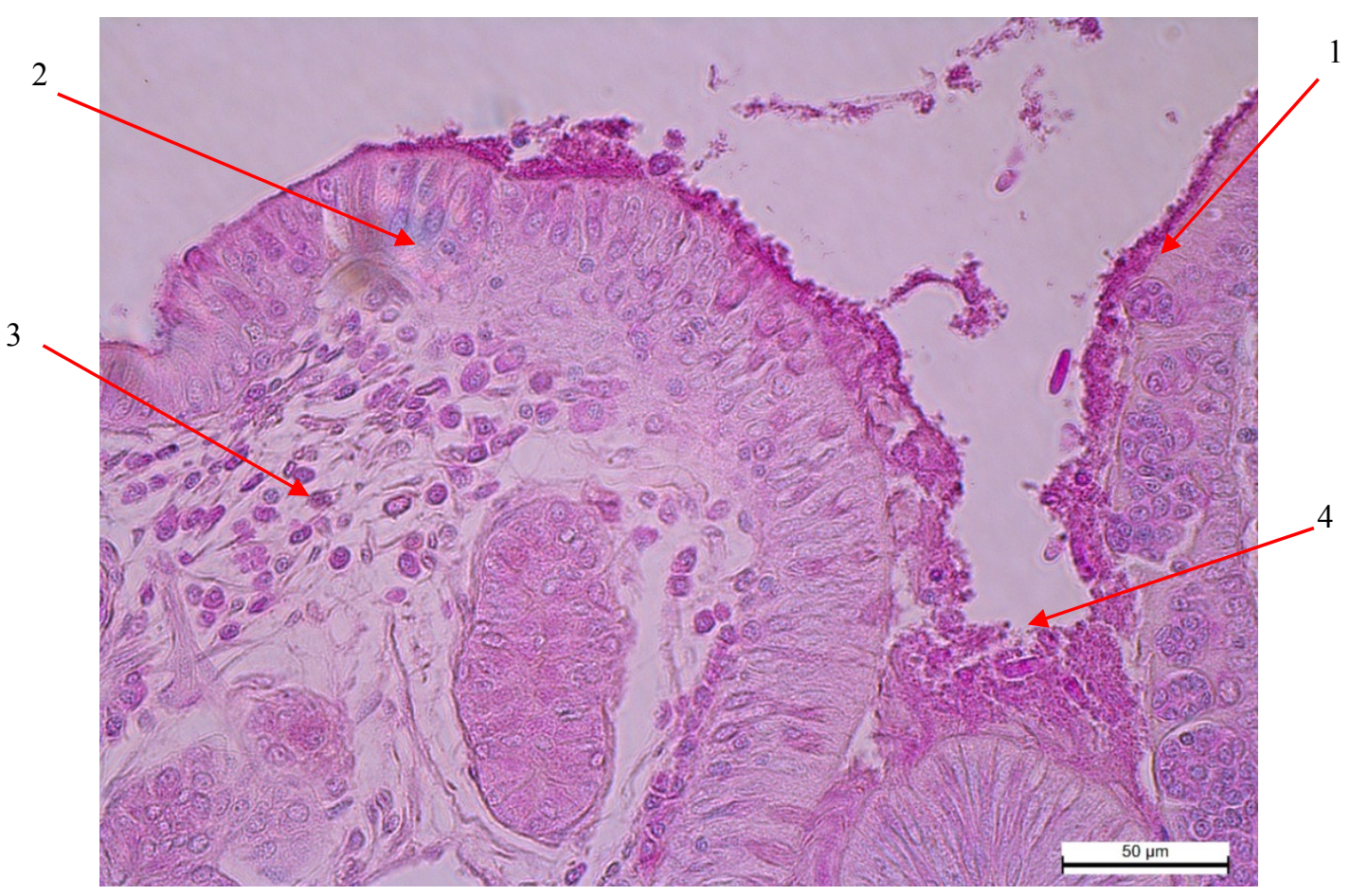

Рис. 7. Червоподібний відросток кролів дослідної групи

1 - слизова оболонка; 2 - підслизова основа; 3 - плазматичні клітини; 4 - слиз

Метиленовий-зелений і піронін $G$ за Браше $x 400$

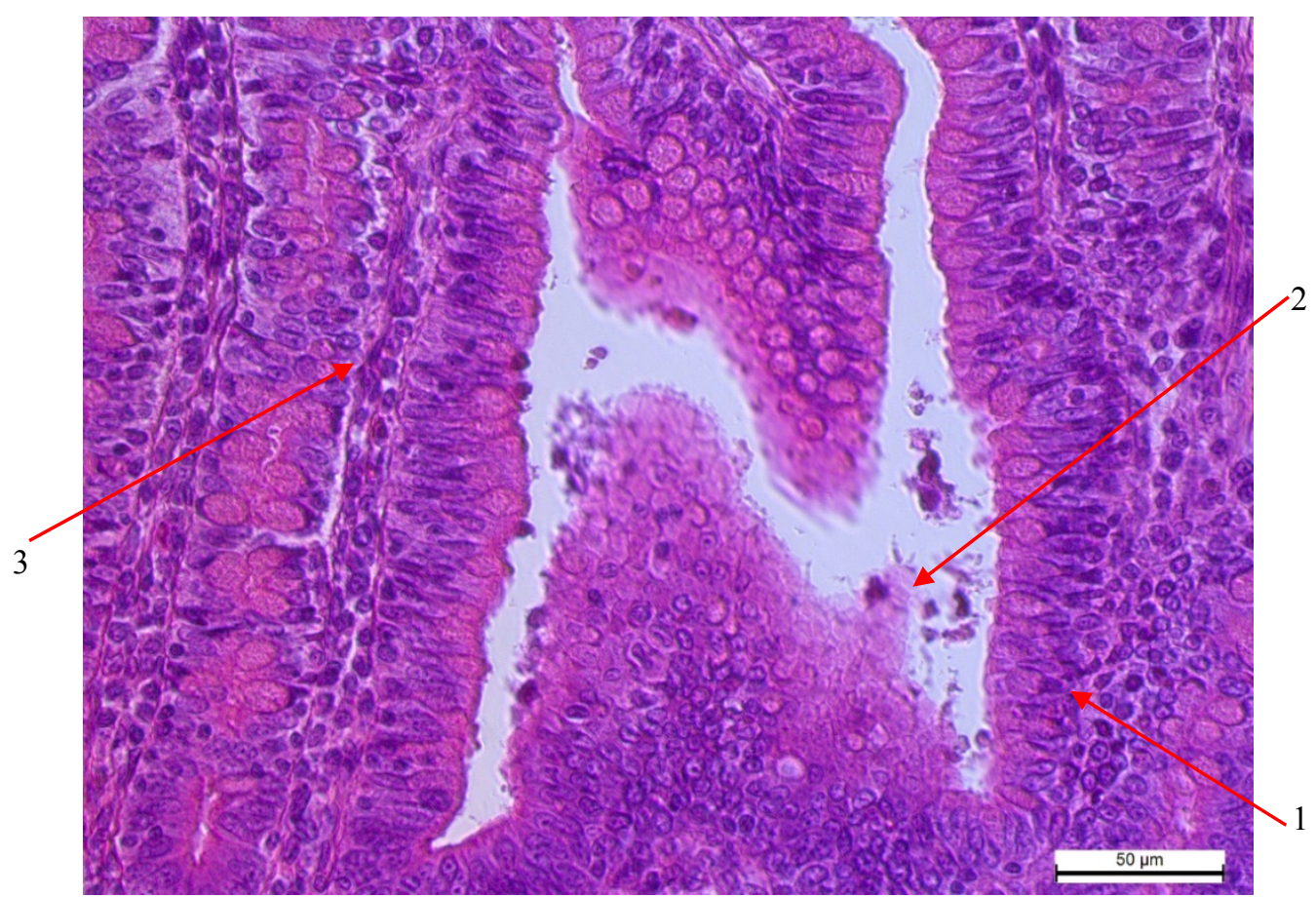

Мал. 8. Червоподібний відросток кролів дослідної групи

1 - келихоподібні клітини; 2 - десквамовані епітеліоцити; 3 - лімфоцити Гематоксилін-еозин х 400

Судини слизової оболонки і підслизової основи розширені, переповнені еритроцитами, містять лімфоцити, реєструється гемоліз еритроцитів (рис. 9). Також спостерігаються помірно виражені периваскулярні набряки. Окремі судини переповнені лімфоцитами. У стромі, особливо поблизу лімфатич- них фолікулів, розташовуються поодинокі лімфоцити, нейтрофіли, макрофаги (рис. 10).

М'язова оболонка червоподібного відростка включає два шари: внутрішній - циркулярний і зовнішній поздовжній. Судини міжм'язової сполучної тканини дещо розширені, переповнені еритроцитами, що містять лімфоцити. 


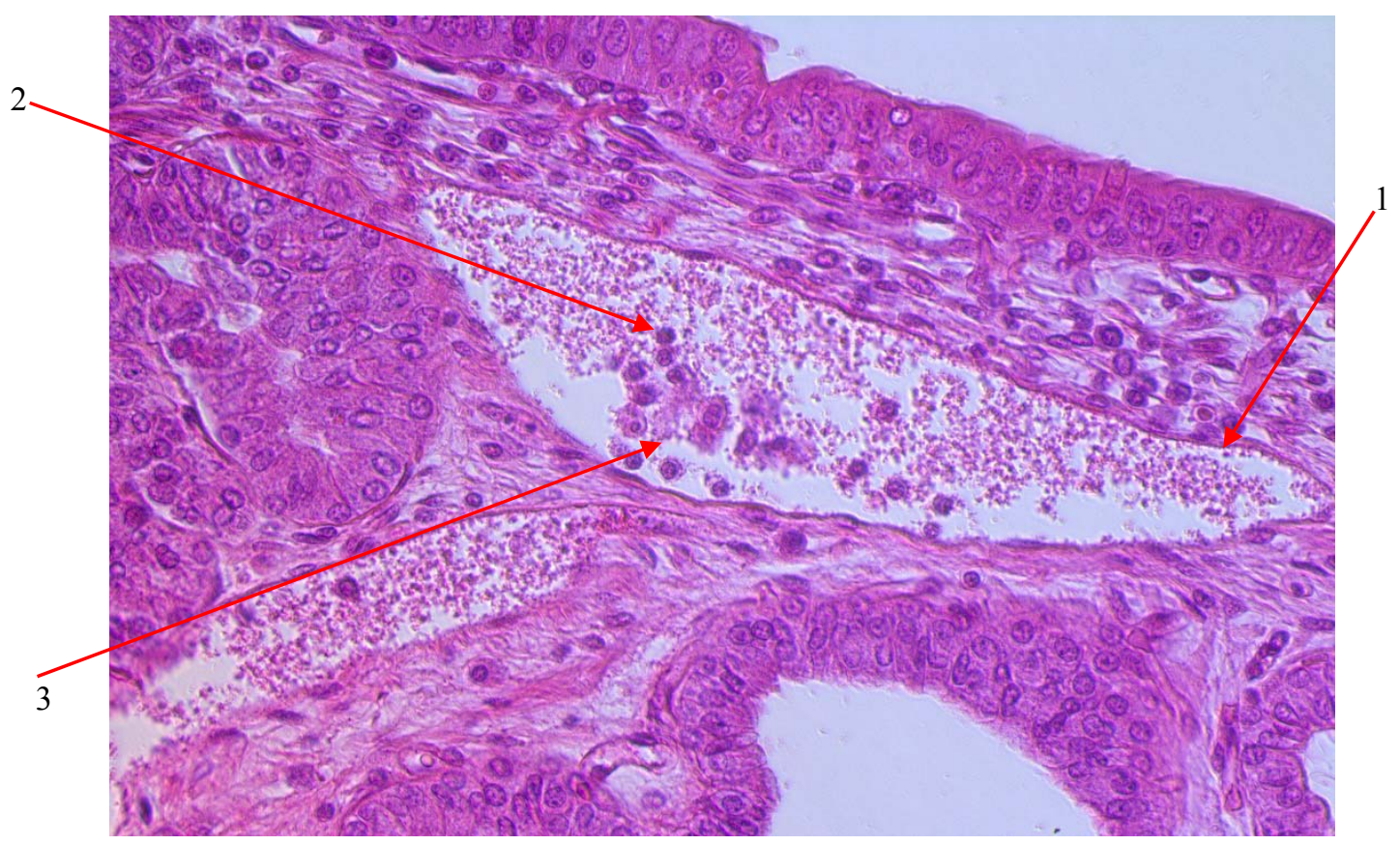

Мал. 9. Червоподібний відросток кролів дослідної групи 1 - судина; 2 - лімфоцити; 3 - гемоліз еритроцитів Гематоксилін-еозин $\times 400$

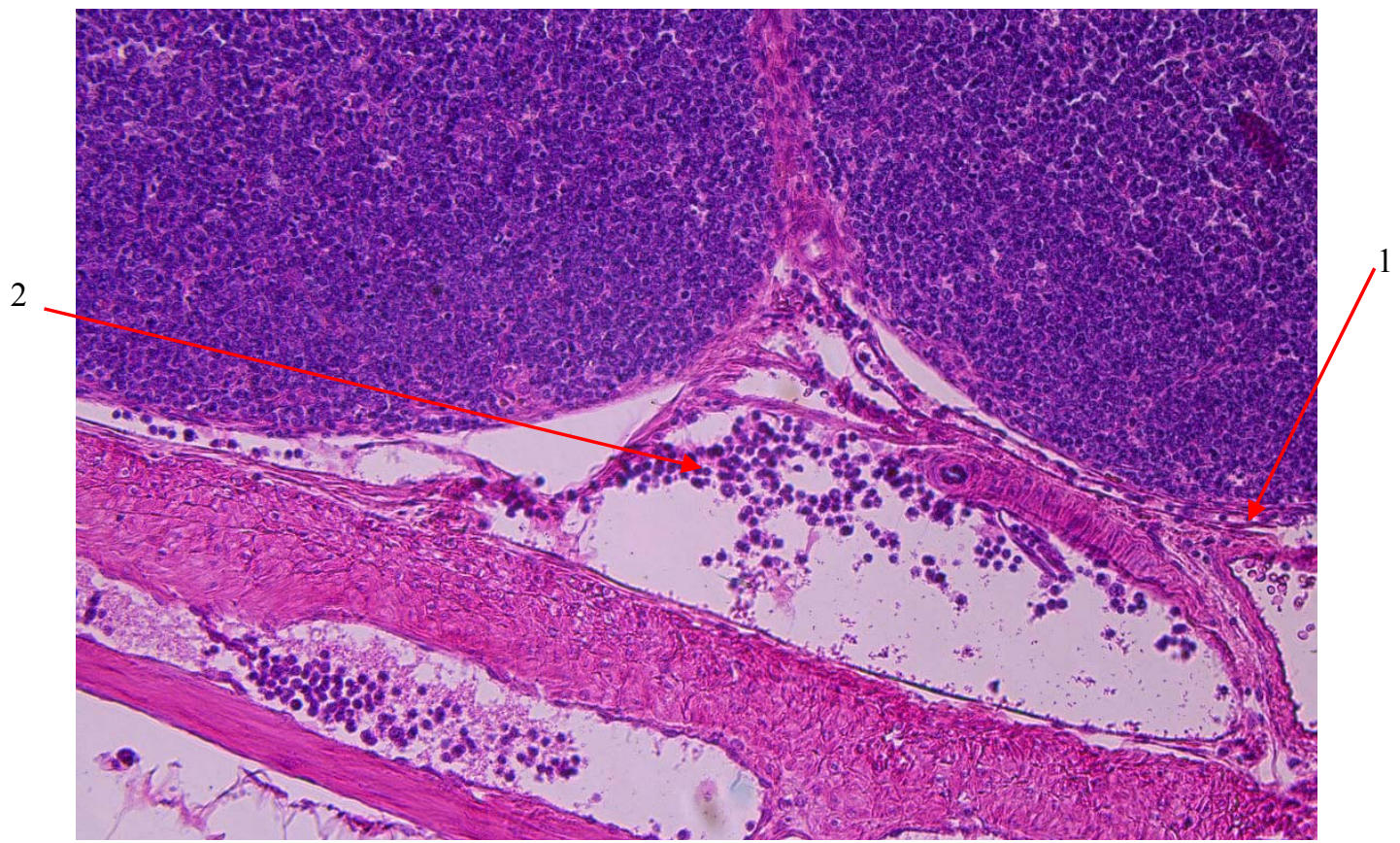

Мал. 10. Червоподібний відросток кролів дослідної групи 1 - судини; 2 - лімфоцити

Гематоксилін-еозин $\times 200$

\section{Висновки}

Гістологічними дослідженнями дивертикулу клубової кишки і червоподібного відростка кролів після парентерального введення їм профілактичного препарату «Пневмо-Про» встановлено:

1) у складі крипт дивертикулу клубової кишки розташовується значна кількість келихоподібних клітин;
2) у центрі підслизових лімфоїдних вузликів знаходиться значна кількість лімфобластів, досить часто візуалізуються мітози лімфоцитів;

3) у куполі підслизових лімфоїдних вузликів розташовуються великі, середні та малі лімфоцити, макрофаги;

4) у власній пластинці і в підслизовій основі червоподібного відростка розташовуються численні, 
об'ємні скупчення лімфоїдної тканини, які формують підслизові скупчення лімфоїдних вузликів;

5) периферична частина лімфоїдних вузликів i міжфолікулярна зона містять значну кількість $\mathrm{T}$ лімфоцитів, присутня переважна більшість вторинних лімфоїдних фолікулів конусоподібної форми.

Це свідчить про підвищення функціональної активності неспецифічних факторів резистентності та імунобіологічної реактивності організму тварин після введення їм профілактичного протипневмококового препарату «Пневмо-Про».

\section{Бібліографічні посилання}

Goral's'kyj, L.P. (2005). Osnovy gistologichnoi' tehniky i morfofunkcional'ni metody doslidzhennja u normi ta pry patologii'. Zhytomyr: Polissja (in Ukrainian).

Datchenko, O.O., Vorob'ev, A.V. (2009). Vlijanie immunostimulirujushhego i probioticheskogo preparatov na morfologicheskie pokazateli organov perifericheskoj immunnoj sistemy laboratornyh zhivotnyh Izvestija Orenburgskogo gosudarstvennogo agrarnogo universiteta. 1(21), 223-225 (in Russian)

Kisera, Ja.V., Storchak, Ju.G. (2015). Dynamika tytru specyfichnyh antytil u syrovatci krovi teljat i koriv pislja vvedennja profilaktychnogo preparatu proty pnevmokokovoi' infekcii'. Naukovyj visnyk L'vivs'kogo nacional'nogo universytetu veterynarnoi' medycyny ta biotehnologij im. S.Z. Gzhyc'kogo. L'viv. 17, 2(62), 62-68 (in Ukrainian).

Kisera, Ja.V., Storchak, Ju.G. (2014). Koryst' ta shkoda riznyh ad'juvantiv pry provedenni specyfichnoi' profilaktyky tvaryn Zhurnal «Sil's'kyj gospodar».L'viv, 1-2, 27-31 (in Ukrainian).

Kisera, Ja.V., Storchak, Ju.G. (2014). Rozrobka inaktyvovanoi' vakcyny proty dyplokokovoi' infekcii'. Naukovyj visnyk L'vivs'kogo nacional'nogo universytetu veterynarnoi' medycyny ta biotehnologij imeni S.Z. Gzhyc'kogo. L'viv, 16. 2(59), 111-117 (in Ukrainian).

Merkulov, G.A. (1996). Kurs patologoanatomicheskoj tehniki. Izd-vo «Medicina», Leningradskoe otdelenie (in Russian).
Roksin, G.I., Levinson, L.B. (1957). Mikroskopicheskaja tehnika. «Sovetskaja nauka». Moskva (in Russian)

Storchak, Ju.G. (2014). Vmist imunoglobuliniv u syrovatci krovi teljat pry provedenni specyfichnoi' profilaktyky pnevmokokovoi' infekcii'. Naukovyj visnyk Bilocerkivs'kogo nacional'nogo agrarnogo universytetu. Bila Cerkva. 14 (114), 88-91 (in Ukrainian).

Storchak, Ju.G. (2015). Zminy morfologichnyh i imunologichnyh pokaznykiv u razi zastosuvannja inaktyvovanoi' autovakcyny $\mathrm{z}$ miscevogo shtamu Streptococcus pneumoniae proty pnevmokokovoi' infekcii' teljat. Naukovyj visnyk Nacional'nogo universytetu bioresursiv ta pryrodokorystuvannja Ukrai'ny. Kyi'v. 217, 171-180 (in Ukrainian).

Storchak, Ju.G. (2014). Inaktyvovana autovakcyna z miscevogo shtamu Streptococcus pneumoniae proty dyplokokovoi' infekcii'. Naukovyj visnyk Nacional'nogo universytetu bioresursiv ta pryrodokorystuvannja Ukrai'ny. - Kyi'v. 201(1), 147152 (in Ukrainian).

Storchak, Ju.G., Kisera, Ja.V. (2014). Pokaznyky imunorektyvnosti organizmu teljat na tli specyfichnoi' profilaktyky streptokokovoi infekcii $\mathrm{z}$ vykorystannjam autovakcyny. Naukovyj visnyk L'vivs'kogo nacional'nogo universytetu veterynarnoi' medycyny ta biotehnologij imeni S.Z. Gzhyc'kogo. L'viv. 16. 3(60), 340-349 (in Ukrainian).

Vol'fgans, Kjunel' (2007). Cvetnoj atlas po citologii, gistologii i mikroskopicheskoj anatomii. per. S angl. E Pogosjan.-M.: AST: Astrel' (in Russian).

Shevchenko, A.A., Shevchenko, L.V., Litvinova, A.R. i dr. (2009). Sovershenstvovanie specificheskoj profilaktiki krupnogo rogatogo skota. Trudy Kubanskogo gosudarstvennogo agrarnogo universiteta. Serija: Veterinarnye nauki, 1(1), 127-129 (in Russian).

Shishkov, V.P., Naletov, N.A. (1980). Patologicheskaja anatomija sel'skohozjajstvennyh zhivotnyh. M.: Kolos (in Russian)

Стаття надійшла до редакичї 7.09.2016 